\title{
Synthesis of Macromolecules and Polyribosome Formation in Early Stages of Spore Germination in Fusarium solani
}

\author{
JEAN C. COCHRANE, T. A. RADO* AND V. W. COCHRANE \\ Department of Biology, Wesleyan University, \\ Middletown, Connecticut 06457, U.S.A.
}

(Accepted for publication 13 November 1970)

\begin{abstract}
SUMMARY
Net synthesis of protein and RNA in germinating macroconidia of Fusarium solani began at the time of appearance of germ tubes, RNA being formed first; net DNA synthesis began much later. Studies on precursor incorporation indicated that the ungerminated spore, at the time of its removal from the parent mycelium, had a low but real capacity to synthesize both RNA and protein. Leucine incorporation rose very rapidly to a maximum at about $40 \mathrm{~min}$. after harvest; even in the time required for conventional washing and filtration, incorporation capacity increased threefold. Ultracentrifuge profiles showed polysome peaks after $15 \mathrm{~min}$. incubation; evidence from ribonuclease treatment was consistent with the existence of polysomes in the spore at the time of removal from the mycelium. Neither protein nor RNA synthesis required a complete medium, but DNA was synthesized only in a medium that supported germination.
\end{abstract}

\section{INTRODUCTION}

The first investigations of the molecular biology of spore germination in higher fungi indicated that ribosomes of the ungerminated spore are not aggregated into polysomes, and that polysomes appear only after the initiation of germination (Henney \& Storck, 1964; Horikoshi, Ohtaka \& Ikeda, 1965). However, both the kinetics of protein synthesis in vivo (Barash, Conway \& Howard, I967; Horikoshi \& Ikeda, I968) and the action of actinomycin D (Dunkle, Maheshwari \& Allen, 1969) suggested that preformed message exists in the ungerminated spore and that the early negative findings should be re-examined.

Evidence of polysomes in ungerminated spores is now documented for uredospores of Uromyces phaseoli (Staples, Bedigian \& Williams, I968), lyophilized basidiospores of Schizophyllum commune (Leary, Morris \& Ellingboe, I969), and conidia of Botryodiplodia theobromae (Brambl \& Van Etten, 1970). In none of these studies, for technical reasons, was it possible to use absolutely fresh spores: the rust uredospores were collected and stored in the cold (Staples, App, McCarthy \& Gerosa, I966); conidia of Botryodiplodia were harvested in water, washed, and stored in the cold for at least a few hours (Van Etten, 1968); and in the procedure of Leary et al. (1969) spores were washed and lyophilized before extraction. Similarly, although the kinetics of protein synthesis in vivo in spores of Aspergillus oryzae suggest a functioning system in the ungerminated spore, the spores for these experiments were obtained from a com-

* Present address: Department of Microbiology, Scripps Clinic and Research Foundation, La Jolla, California 92037, U.S.A. 
mercial source and harvesting and storage conditions were not specified (Horikoshi et al. 1965).

This paper reports studies in vivo and in vitro on the macroconidia of Fusarium solani, made with particular attention to the problem of determining synthetic activity as soon as possible after separation of the spores from the parent sporophores. Incorporation of precursors and the question of the existence of polysomes are considered here; preliminary experiments (unpublished) show that cell-free preparations from ungerminated and from germinated spores are able to incorporate phenylalanine and leucine into trichloracetic acid-insoluble materials, the former with polyuridylic acid as template, the latter with endogenous messenger.

\section{METHODS}

Organism and cultivation. A strain pathogenic to Phaseolus vulgaris of Fusarium solani (Mart.) Appel \& Wr. f.sp. phaseoli (Burk) emend. Snyd. \& Hans., was used, originally from the culture collection of $\mathrm{Dr}$ W. C. Snyder, and selected for macrospore production.

This strain produced macrospores after 7 days on a glucose + nitrate + salts + agar medium (Cochrane \& Cochrane, I966); $400 \mathrm{ml}$. medium in a Fenbach flask yielded about 2 g. (wet wt) spores. For germination by germ tube, the organism required, in addition to sources of carbon, nitrogen and inorganic ions, a factor in yeast extract replaceable by ethanol (Cochrane, Cochrane, Simon \& Spaeth, I963).

Spores were harvested on $4 \mathrm{I}-\mathrm{H}$ Whatman filter paper in sterile cold $\left(4^{\circ}\right) 0^{\circ} \mathrm{I} \mathrm{M}$ $\mathrm{KH}_{2} \mathrm{PO}_{4}-\mathrm{K}_{2} \mathrm{HPO}_{4}$ buffer ( $\mathrm{pH} \mathrm{6.5)}$, washed twice on the filter with the same buffer, and suspended in the buffer at I g. (wet wt) per $50 \mathrm{ml}$. One-tenth volume of this spore suspension, yielding a final spore concentration of $2 \mathrm{mg} . / \mathrm{ml}$. ( $\mathrm{I} \cdot \mathrm{I}$ to $\mathrm{I} \cdot 4 \times 10^{6}$ spores $/$ $\mathrm{ml}$.), was added to the appropriate medium.

The complete germination medium contained glucose, $20 \mathrm{~mm} ; \mathrm{NH}_{4} \mathrm{H}_{2} \mathrm{PO}_{4}, 4 \mathrm{mM}$; $\mathrm{MgSO}_{4}, 2 \mathrm{mM}$; ethanol, $6 \mathrm{~mm}$; and $\mathrm{KH}_{2} \mathrm{PO}_{4}-\mathrm{K}_{2} \mathrm{HPO}_{4}$ buffer (pH 6.5), 30 mM. Ethanol was sterilized by filtration, the other constituents by autoclaving $\mathrm{I} 5 \mathrm{~min}$. at $\mathrm{I} 2 \mathrm{I}^{\circ}$, the glucose separately. In experiments in which germination was not desired, ethanol was omitted. In all experiments except those of Fig. I, spores were incubated in flasks on a reciprocating shaker (stroke $3.6 \mathrm{~cm}$., $96 \mathrm{cycles} / \mathrm{min}$.) at $25^{\circ}$. For the analyses of Fig. I a stirred and aerated fermentor (Fermentation Design, Inc., Allentown, Pa) was used with $2500 \mathrm{ml}$. of complete medium in a 51 . jar; aeration at I vol. air/vol. medium/min., and a stirring rate of $400 \mathrm{rev} . / \mathrm{min}$. Under these conditions the rate of germination was the same as that found in shaken fiasks.

Chemical determinations. Protein was determined by the method of Lowry, Rosebrough, Farr \& Randall (I95I), using bovine serum albumin (Armour) as the standard. RNA was estimated by the orcinol method (Schneider, 1957), with yeast RNA (Sigma Chemical Co.) as the standard; the crude value was corrected for DNA. DNA was determined by the method of Burton (1956), modified by the substitution of $\mathrm{I} \cdot \mathrm{O} \mathrm{N}$ for $0.5 \mathrm{~N}$ perchloric acid.

Whole organisms which had been exposed to radioactive precursors were fractionated by consecutive extractions (with intermediate washings) by cold $5 \%(\mathrm{w} / \mathrm{v}$ ) trichloracetic acid (TCA), hot $5 \%(\mathrm{w} / \mathrm{v}) \mathrm{TCA}$, and $0.2 \mathrm{~N}-\mathrm{NaOH}$ for pool, nucleic acids and protein, respectively. Protein was routinely precipitated with $5 \%(\mathrm{w} / \mathrm{v})$ 
TCA, washed, and redissolved in $0 \cdot 2 \mathrm{~N}-\mathrm{NaOH}$ before counting. Radioactivity was determined by liquid scintillation counting, with correction for quenching by the channels ratio method.

Preparation of extracts. After harvest from the agar medium and washing as described, with ice-cold phosphate buffer, organisms were quickly filtered and the filter cake was placed in a chilled mortar at $-5^{\circ}$ with twice its weight of chilled $0.2 \mathrm{~mm}$. glass beads. Three volumes of buffer (buffer C) containing tris-acetate $(\mathrm{pH} 7 \cdot 6)$ $0.06 \mathrm{M} ; \mathrm{Mg}$ acetate, 0.005 $\mathrm{M} ; \mathrm{KCl}, 0.0 \mathrm{M}$; spermidine, $0.0006 \mathrm{M}$; and Bentonite, $2 \mathrm{mg}$./ml. were added. This procedure was adapted from Bretthauer et al. (1963). Freshly harvested (zero time) spores were ground with a pre-chilled pestle for I min., spores harvested after incubation were ground $45 \mathrm{sec}$; 故e fresh spores were more resistant to rupture.

All extracts were centrifuged I5 min. at I2,000 $\mathrm{g}$ in a Sorvall RC-2 B centrifuge; the supernatants obtained were used in all experiments on cell-free preparations.

Sucrose density-gradient analysis. Preparative sucrose-gradient centrifugation was accomplished using $5.2 \mathrm{ml}$. of linear 15 to $30 \%(\mathrm{w} / \mathrm{v})$ solutions of RNase-free sucrose (Schwarz BioResearch) in buffer C. Tubes were prepared by layering $75 \mu \mathrm{l}$. of the $12,000 \mathrm{~g}$ supernatant on each gradient, and the samples were spun for $50 \mathrm{~min}$. in an SW 50.I rotor in the Spinco Model L2-65 B ultracentrifuge at a maximum force of $300,000 \mathrm{~g}$. At the end of each run, the gradients were pumped through a Gilford recording spectrophotometer and the extinction at $260 \mathrm{~nm}$. was continuously monitored. RNase digestions were performed by adding $2.5 \mu \mathrm{g}$. of crystalline enzyme (Boehringer, Mannheim) to I $\mathrm{ml}$. aliquots of the $12,000 \mathrm{~g}$ supernatants. Hydrolysis was allowed to continue for $5 \mathrm{~min}$. at $0^{\circ}$, at which time both treated and untreated samples were applied to gradients.

\section{RESULTS}

\section{Macromolecular synthesis during germination}

Results of analyses for protein, RNA, and DNA are shown in Fig. I. These measurements were made on samples from a stirred and aerated fermentor in which the rate of germination was the same as that in the shaken flasks used in all other experiments. The sequence of initiation of syntheses (RNA first, then protein, then DNA) was the same as had been reported for conidia of higher fungi (Yanagita, 1957; Barash, 1968), although in Microsporum gypseum protein synthesis had been found to begin before RNA synthesis (Barash et al. 1967 ).

DNA synthesis during germination began only at $8 \mathrm{~h} .(8 \mathrm{I} \cdot 5 \%$ germination) and rose in the next $4 \mathrm{~h}$. to $2 \cdot 7$ times the initial level. The apparent conflict between these chemical data and the observation of Marchant (1966) that nuclei of Fusarium culmorum spores divided early in the germination period has not been resolved.

Spores which were not able to germinate because of a nutritional restriction (Fig. I) were able to synthesize both protein and RNA at slow rates; both only doubled over the $12 \mathrm{~h}$. period, whereas protein rose fourfold and RNA sevenfold during germination. Net DNA synthesis began only after germination was complete and did not occur in non-germinating spores in the $\mathrm{I} 2 \mathrm{~h}$. of the experiment.

Dry-weight determinations were made but are not included in Fig. I. Germinating spores doubled in dry weight in to h., while non-germinating spores increased only $20 \%$. 

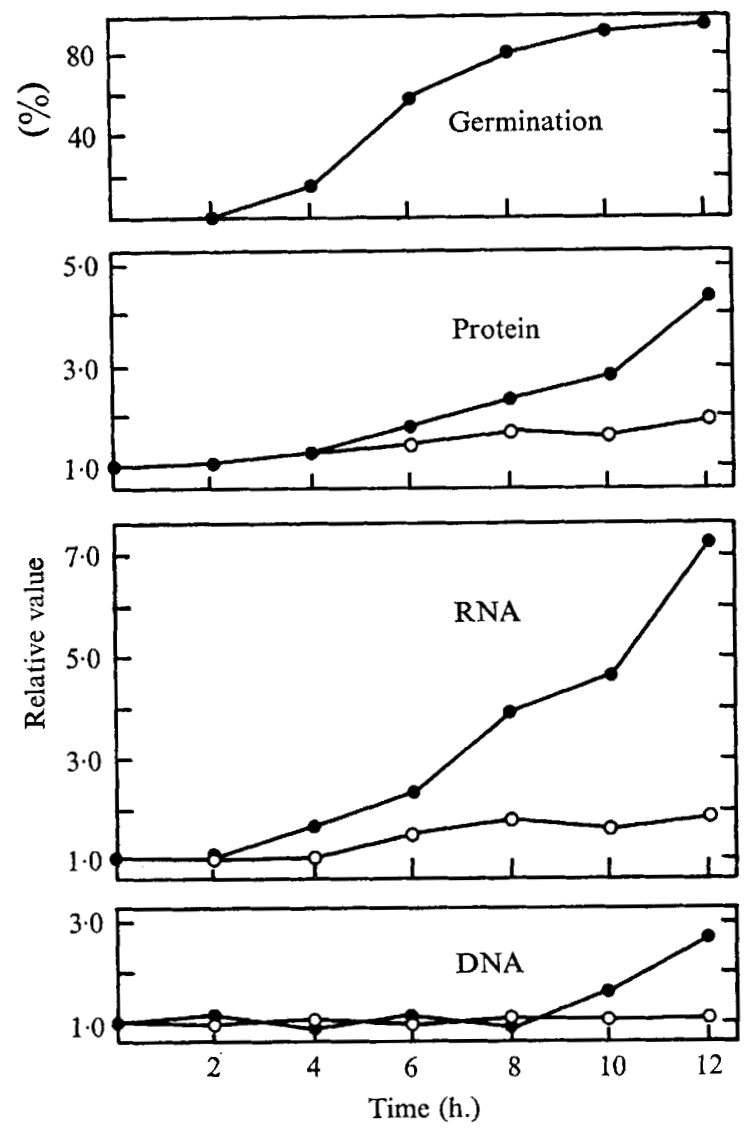

Fig. I. Macromolecular syntheses in macrospores of Fusarium solani. Germinating spores (๑) were incubated in $2500 \mathrm{ml}$. of complete medium in a stirred and aerated fermentor at $25^{\circ}$ and sampled at the times shown. Non-germinating spores $(O)$ were incubated similarly in the same medium lacking ethanol. Ordinate values are relative to composition at zero time (zero-time values, in $\mu \mathrm{g} . / \mathrm{mg}$. dry wt: RNA $28 \cdot 3$, protein 15I, DNA 2.66).

\section{Precursor incorporation during early development}

Leucine and uracil incorporation by washed spores in complete medium is shown in Fig. 2. Absolute rates of total incorporation of leucine and uracil were markedly different, e.g. uptake of leucine in the first $20 \mathrm{~min}$. was $0.32 \mathrm{nmoles} / \mathrm{min}$. $/ \mathrm{mg}$. fresh wt and that of uracil $0.058 \mathrm{nmoles} / \mathrm{min} . / \mathrm{mg}$. fresh wt. The uptake of $\left[{ }^{3} \mathrm{H}\right]$ uridine was even slower than that of uracil but the kinetics were similar.

For incorporation of both precursors into macromolecules the data of Fig. 2(b) show increasing rates with time, but no evidence of as pronounced a lag period such as that reported for the uptake of mixed amino acids by conidia of Aspergillus niger (Horikoshi \& Ikeda, 1968) or of uracil into spores of Botryodiplodia theobromae (Brambl \& Van Etten, 1970). Total uptake (largely in the acid-soluble pool) was at all times well in excess of that incorporated into macromolecules; there is therefore no evidence that permeability was a limiting factor in synthesis. 
The slow rate of uracil (and of labelled uridine) uptake made pulse experiments impracticable; incorporation of leucine during 5 min. pulses is shown in Fig. 3 as a function of incubation time in complete medium. The principal finding was that substantial incorporation occurred at 'zero time' (actually a 5 min. pulse begun at zero time). This supported the data of Fig. 2 in suggesting that the spores, as prepared, possessed at least a limited capacity for protein synthesis. Pulse experiments on other fungal spores are in general agreement (Barash et al. 1967; Brambl \& Van Etten, 1970).

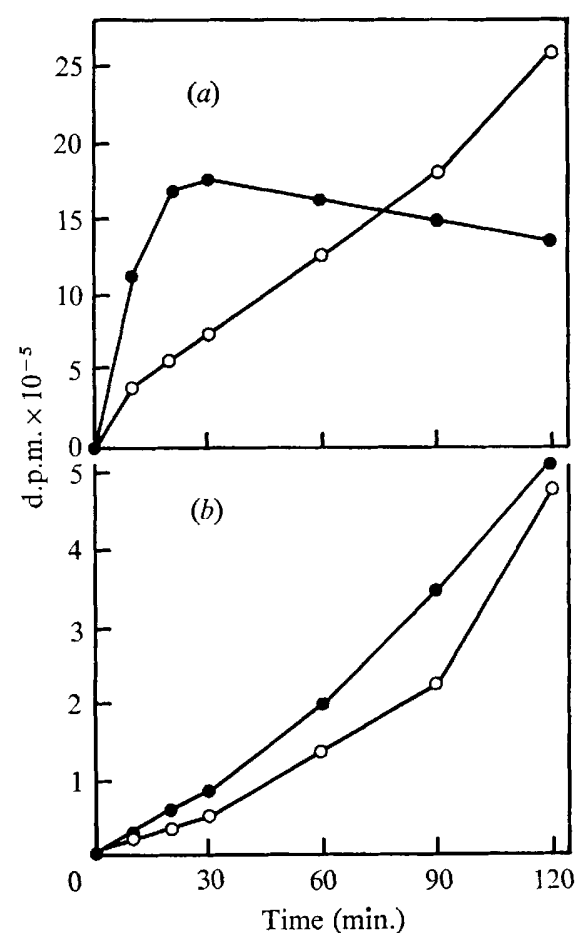

Fig. 2. The incorporation of leucine and uracil by macrospores of Fusarium solani. LeucineU-14 C (204 nmoles, $17.8 \times 10^{5}$ d.p.m.) or uracil-2-14 C (580 nmoles, $94.8 \times 10^{5}$ d.p.m.) was added to $15 \mathrm{ml}$. of complete germination medium containing $30 \mathrm{mg}$. (fresh wt) of washed spores, and incubated for the time shown. (a) Total uptake of leucine $(\bullet)$ and of uracil $(O)$ by cells. $(b)$ Incorporation of leucine into protein $(\bullet)$, and of uracil into the nucleic acid fraction $(O)$.

The rate of incorporation into protein reached a plateau at $\mathrm{I} 5$ to $30 \mathrm{~min}$. and did not appreciably change thereafter; in experiments not recorded here the plateau was found to extend to $6 \mathrm{~h}$., i.e. to the time of about $50 \%$ germination. These are specific activity values; as expected from the protein synthesis data of Fig. I, total incorporation into protein in a pulse experiment rose after 4 to $6 \mathrm{~h}$. Omission of ethanol or both glucose and ethanol from the medium made no difference to the shape of the curve of Fig. 3, i.e. non-germinating spores behaved as did germinating ones for the first $2 \mathrm{~h}$. of incubation.

The ratio of leucine incorporated into protein to that taken up by the organisms (Fig. 3) was 0.13 at 'zero time', rose to 0.28 at $30 \mathrm{~min}$. and reached a steady value of about 0.23 thereafter. Again it seemed that within 5 min. a functioning system for protein synthesis could be demonstrated. These pulse experiments contrast with 
results reported with the very different zoospores of the aquatic fungus Blastocladiella emersonii (Lovett, 1968), in which a leucine pulse earlier than 15 to $20 \mathrm{~min}$. was not incorporated into protein; in this organism dissolution of a nuclear cap is a necessary precondition of protein synthesis.

In the experiments so far described, spores were harvested in distilled water, filtered, washed twice, resuspended in phosphate buffer, and only then added to the medium. Under these conditions 'zero time' spores were in fact exposed to hydration for 5 to $8 \mathrm{~min}$. before coming in contact with the labelled precursor. In view of the finding that hydration may trigger changes in macromolecular synthetic activity in pollen (Mascarenhas \& Bell, 1969) and seeds (Marcus \& Feeley, 1965), a different experimental approach was tried.

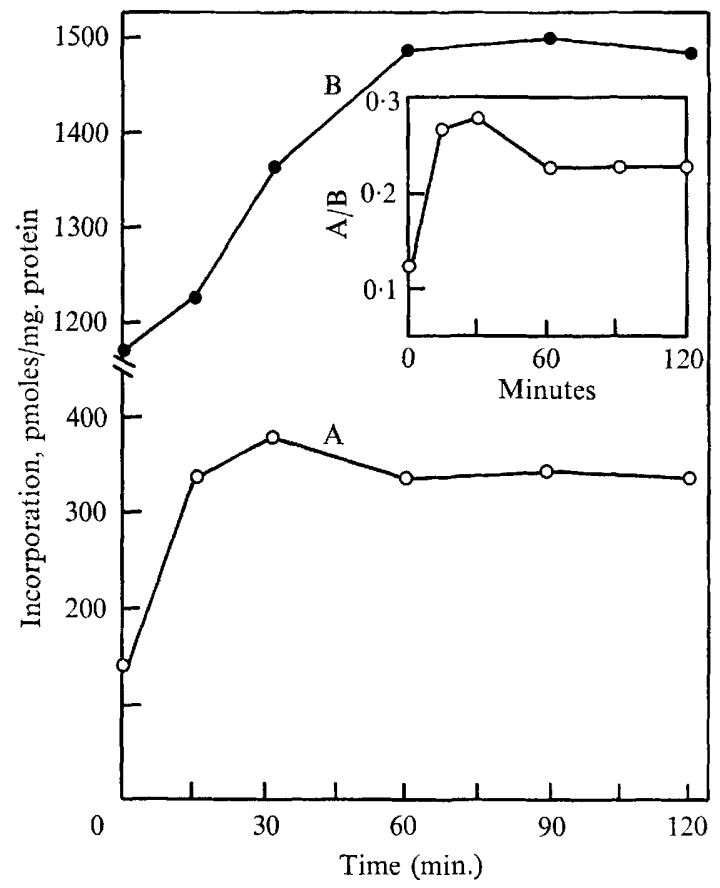

Fig 3. The incorporation of leucine- $\mathrm{U}-{ }^{14} \mathrm{C}$ in 5 -min. pulses by macrospores of Fusarium solani: , total cell incorporation; $O$, incorporation into protein. Macrospores $(30 \mathrm{mg}$. fresh wt) were incubated in complete germination medium ( $5 \mathrm{ml}$.). At the times shown, leucine-U${ }^{14} \mathrm{C}(\mathrm{I} \cdot 53$ nmoles, $0.4 \mu \mathrm{Ci})$ was added; cells were harvested $5 \mathrm{~min}$. later and fractionated. Points are placed at the beginning of the pulse period.

Here (Table $\mathrm{r}$ ) spores were scraped from the agar surface with a razor blade, weighed, and added directly to flasks containing the labelled precursor. Dry weights of samples could not be controlled more closely than to $\pm 10 \%$; therefore the appropriate measure of incorporating ability was taken to be the specific activity of the protein.

The results showed substantial incorporation of leucine, by scraped spores, into the hot TCA-insoluble material in $2.5 \mathrm{~min}$., and about twice as much incorporation in $5 \mathrm{~min}$. Cycloheximide inhibited the process $98 \%$ (with only a minor inhibition of incorporation into the TCA-soluble, or 'pool', fraction). The usual washing and 
filtration of spores (Table I, line 4) clearly permitted more rapid incorporation into protein (almost threefold) but there was no difference in the total uptake, in Io min., between scraped spores and washed spores. We may conclude, therefore (I) that the protein synthetic capacity of the unhydrated spores was real but significantly lower than that of washed spores, and (2) that this difference could not be attributed to differences in permeability to or accumulation of the precursor amino acid $(95 \%$ or more of the non-protein label was in the pool extractable with cold $5 \%$ TCA). Thus, with pools of the same size, unwashed spores had $6 \%$ of the total cell leucine in protein, whereas washed spores had $18 \%$ in protein.

\section{Table I. Initial rates of leucine- $U-{ }^{14} C$ incorporation*}

$\begin{array}{ccccc}\begin{array}{c}\text { Spore } \\ \text { preparation }\end{array} & \begin{array}{c}\text { Cycloheximide } \\ (\mu \mathrm{g} . / \mathrm{ml} .)\end{array} & \begin{array}{c}\text { Incubation } \\ \text { (min.) }\end{array} & \text { Cells } & \begin{array}{c}\text { Incorporation } \\ \text { (pmoles/mg. protein) }\end{array} \\ \text { Scraped } \dagger & 0 & 2 \cdot 5 & 594 & 31 \cdot 6 \\ \text { Scraped } \dagger & 0 & 5 \cdot 0 & 1250 & 75 \cdot 2 \\ \text { Scraped } \dagger & 10 & 5 \cdot 0 & 938 & 1 \cdot 47 \\ \text { Washed } \ddagger & 0 & 5 \cdot 0 & 1210 & 212\end{array}$

* Macrospores (about $30 \mathrm{mg}$. fresh wt) were added at zero time (see text) to $15 \mathrm{ml}$. of complete germination medium containing leucine-U- ${ }^{14} \mathrm{C}(\mathrm{I} \cdot 8$ nmoles, $0.4 \mu \mathrm{Ci})$ and cycloheximide as shown.

$\dagger$ Macrospores scraped from agar surface and transferred without washing to the incubation medium.

$\ddagger$ Macrospores harvested in buffer and washed (see Methods).

For the first conclusion above to be valid, it must be shown: (i) that extracts from ungerminated spores can synthesize protein, at least so far as incorporation of labelled amino acids is indicative of this process; and (ii) that polysomes should exist in ungerminated spores, although not necessarily in large numbers. The first of these tests was described in a separate paper (Rado \& Cochrane, I97I); the second is considered next.

Polysomes in ungerminated and germinated spores. In an effort to obtain valid sedimentation patterns from spores, a number of disruptive procedures were tried. Extracts prepared by disrupting the spores in a French pressure cell at a pressure of $20,000 \mathrm{lb} / \mathrm{sq}$. in. were shown to contain only $80 \mathrm{~S}$ monomeric units in spite of the presence of Bentonite in the suspension buffer and the maintenance of temperatures within the range $o$ to $5^{\circ}$. Rapidly sedimenting material was also absent from extracts prepared by freezing the spore cake to the temperature of solid $\mathrm{CO}_{2}$ and subsequently grinding in a mortar at the same temperature, using crushed solid $\mathrm{CO}_{2}$ as abrasive (J. S. Lovett, personal communication). The absence of rapidly sedimenting material in extracts prepared by these methods led eventually to the adoption of the procedure described in Methods. Use of this method resulted in extracts containing rapidly sedimenting material only when the grinding time was kept well below 2 min.

Macroconidia incubated in complete medium for 15 min., $4 \mathrm{~h}$. and $12 \mathrm{~h}$. were shown to contain material which sedimented more rapidly than the $80 \mathrm{~S}$ peak and which was digestible by RNase (Fig. 4). In addition to showing an increase in the amount of heavy material present in the extracts, the graphs indicate that the actual peaks representing aggregates of specific size classes also became more clearly defined with time. Since all the heavy peaks increased proportionally, it is likely that an 
equivalent increase occurred in the amount of each of the ribosome classes present at the earliest time; this tends to rule out the preferential synthesis of any one class. Planimetric analyses of the areas under the $80 \mathrm{~S}$ peaks of digested and non-digested extracts showed that, between $15 \mathrm{~min}$. and $4 \mathrm{~h}$. in ethanol-containing medium, the amount of RNase digestible material increased nearly threefold and that between 4 and $12 \mathrm{~h}$. another twofold increase occurred.

Freshly harvested macroconidia, and conidia incubated for $15 \mathrm{~min}$. and for $4 \mathrm{~h}$. in medium without ethanol, were found to contain rapidly sedimenting, RNase-digestible material (Fig. 5). The amount of RNase-digestible material increased at the same rate in non-germinating spores as in germinating spores, and the total increase in the period between $15 \mathrm{~min}$. and $4 \mathrm{~h}$. was approximately fourfold. The studies on nongerminated spores indicated that, as with the germinated spores, the increase in the

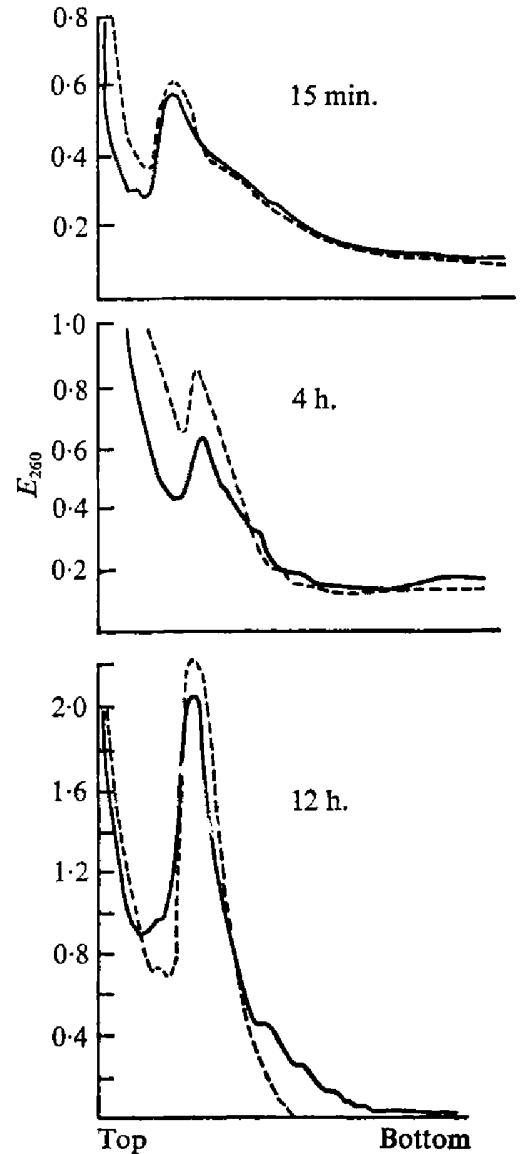

Fig. 4
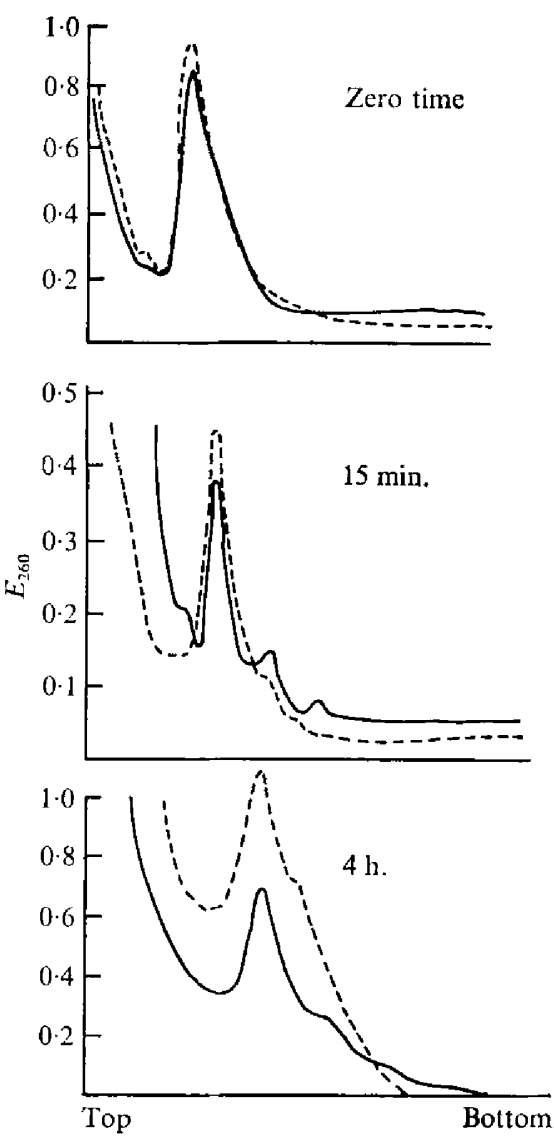

Fig. 5

Fig. 4. Sucrose gradient ( 15 to $30 \%$ ) analysis of $12,000 \mathrm{~g}$ supernatants from macrospores shaken in complete germination medium for the time indicated. - - Untreated supernatants; - - -, supernatants treated with RNase $\left(2.5 \mu \mathrm{g} . / \mathrm{ml}\right.$.) $5 \mathrm{~min}$. at $0^{\circ}$. Germination, $95 \%$ at $12 \mathrm{~h}$.

Fig. 5. Sucrose-gradient analysis of $12,000 \mathrm{~g}$ supernatants from macrospores shaken in complete medium lacking ethanol for the times shown. Conventions and treatment as in Fig. 4. Spore germination did not occur at any time period. 
amount of $E_{280}$ material sedimenting more rapidly than the monosomes was the result of generalized polyribosome formation rather than specific synthesis of any one size class. It should be noted that although no rapidly sedimenting peaks were observed in the extracts of zero-time ungerminated (freshly harvested) spores, the increase in magnitude of the $80 \mathrm{~S}$ peak after R Nase treatment of the extracts strongly suggest that polyribosomes were present (see Discussion).

The extreme lability of the polyribosomes is demonstrated by the care which had to be taken during cell disruption to avoid their breakage. Studies of the grinding procedure indicated that freshly harvested spores had to be ground for more than the time required to break spores which had previously been incubated in medium. The necessity of using a harsher disruptive procedure (longer grinding) may account for the difficulty encountered in obtaining clearly defined polyribosomes from zero-time material. The importance of using an RNase inhibitor during preparation of extracts is made clear by the observation that none of the classes of spores studied yielded polyribosomes when Bentonite was left out of the grinding and suspension buffers.

\section{DISCUSSION}

The sequence of macromolecular syntheses during germination is, as noted earlier, in agreement with some, but not all, other studies on the conidia of higher fungi. This sequence (RNA first, then protein, then DNA) has also been reported in zoospore germination in Blastocladiella emersonii (Lovett, 1968) and in zinc-deficient Rhizopus nigricans mycelium after provision of adequate zinc (Wegener \& Romano, I963).

This sequence is also the same during the outgrowth of bacterial endospores (Hansen, Spiegelman \& Halvorson, 1970). Note that the term 'germination' is used in work on fungal spores to comprise all events from first contact with the medium to formation of the final structure, whereas in bacteria the same term has been limited to describe only the initial transformation of (usually) heat-activated endospores from a dormant to a metabolically active state (Hansen et al. 1970).

Kinetic and pulse experiments reported here show that the macroconidium has, within a few minutes of removal from the parent mycelium, the capacity to incorporate precursors into RNA and protein. Incorporation by itself does not bear on the problem of specific syntheses, which may be critical in the germination process.

Defined polysome peaks appear within I 5 min., both in complete medium and in a medium not permitting germ-tube formation. The claim for the presence of polysomes at zero time rests on the assumption that the shift of RNase-digestible material from the heavy region of the ultracentrifuge profile to the region of the monoribosome peak reflects dissociation of polysomes by the enzyme. This assumption has been made in several studies on dormant structures: seeds (Marcus \& Feeley, 1965), animal eggs (Golub \& Clegg, 1968), bacterial endospores (Chambon, Deutscher \& Kornberg, I968), and pollen (Mascarenhas \& Bell, I969).

As mentioned in the Introduction, indubitable polysome peaks have been shown in ungerminated spores of other fungi. The experiments reported here differ in that the time interval between harvest and extraction has been reduced to a few minutes. The experiments in vivo point to the importance of the time factor; evidently, in Fusarium solani at least a very rapid development of synthetic capacity occurs during the conventional washing procedure. 
It should be noted that macroconidia of Fusarium solani taken directly from the medium by scraping are in a slimy matrix: dry spores of such fungi as Neurospora or Aspergillus, if collected without hydration and tested immediately, may show still a different pattern.

This investigation was supported by U.S. Public Health Service grant no. ROI-AI$0755^{8}$ from the National Institute of Allergy and Infectious Diseases. The authors thank Jane Viggiani for valuable technical assistance and William E. Bruner for studies on analytical methods.

Part of this work was included in a Ph.D. thesis by T. A. Rado presented to Wesleyan University.

\section{REFERENCES}

BARASH, I. (1968). Liberation of polygalacturonase during spore germination by Geotrichum candidum. Phytopathology 58, 1364-1371.

Barash, I., Conway, M. L. \& Howard, D. H. (1967). Carbon catabolism and synthesis of macromolecules during spore germination of Microsporum gypseum. Journal of Bacteriology 93, 656662.

BRAMBL, R. M. \& VAN ETTEN, J. L. (1970). Protein synthesis during fungal spore germination. V. Evidence that the ungerminated conidiospores of Botryodiplodia theobromae contain messenger ribonucleic acid. Archives of Biochemistry and Biophysics 137, 442-452.

Bretthauer, R. K., Marcus, L., Chaloupka, J., Halvorson, H. O. \& Bock, R. M. (I963). Amino acid incorporation into protein by cell-free extracts of yeast. Biochemistry 2, 1079-1084.

BurToN, K. (1956). A study of the conditions and mechanism of the diphenylamine reaction for the colorimetric estimation of deoxyribonucliec acid. Biochemical Journal 62, 315-322.

Chambon, P., Deutscher, M. P. \& Kornberg, A. (1968). Biochemical studies of bacterial sporulation and germination. X. Ribosomes and nucleic acids of vegetative cells and spores of Bacillus megaterium. Journal of Biological Chemistry 243, 51 I0-51 16.

Cochrane, J. C., Cochrane, V. W., Simon, F. G. \& Spaeth, J. (I963). Spore germination and carbon metabolism in Fusarium solani. I. Requirements for spore germination. Phytopathology 53, 1155II60.

Cochrane, V. W. \& Cochrane, J. C. (1966). Spore germination and carbon metabolism in Fusarium solani. V. Changes in anaerobic metabolism and related enzyme activities during development. Plant Physiology 4r, 8I0-814.

Dunkle, L. D., MAHEShwARI, R. \& Allen, P. J. (1969). Infection structures from rust uredospores: effect of RNA and protein synthesis inhibitors. Science, Washington 163, 48I-482.

Golub, A. L. \& CleGG, J. S. (1968). Protein synthesis in Artemia salina embryos. I. Studies on polyribosomes. Developmental Biology 17, 644-656.

Hansen, J. N., Spiegelman, G. \& Halvorson, H. O. (1970). Bacterial spore outgrowth: its regulation. Science, Washington 168, 129I-I 298.

HeNNEY, H. R. \& STORCK, R. (1964). Polyribosomes and morphology in Neurospora crassa. Proceedings of the National Academy of Sciences of the United States of America 5r, 1050-1055.

HoRIKoshI, K. \& IKEDA, Y. (1968). Studies on the conidia of Aspergillus oryzae. VII. Development of protein synthesizing activity during germination. Biochimica et biophysica acta 166, 505-511.

HoRIKOSHI, K., OHTAKA, Y. \& IKEDA, Y. (I965). Ribosomes in dormant and germinating conidia of Aspergillus oryzae. Agricultural and Biological Chemistry 29, 724-727.

Leary, J. V., Morris, A. J. \& Ellingboe, A. H. (1969). Isolation of functional ribosomes and polysomes from lyophilized fungi. Biochimica et biophysica acta 182, I1 3-120.

LOVETT, J. S. (1968). Reactivation of ribonucleic acid and protein synthesis during germination of Blastocladiella zoospores and the role of the ribosomal nuclear cap. Journal of Bacteriology 96 , 962-969.

Lowry, O. H., Rosebrough, N. J., FarR, A. L. \& Randall, R. J. (1951). Protein measurement with the phenol reagent. Journal of Biological Chemistry 193, 265-275. 
MARCHANT, R. (1966). Fine structure and spore germination in Fusarium culmorum:" Annals of Botany 3o, 44 $\mathrm{I}-446$.

Marcus, A. \& Feeley, J. (1965). Protein synthesis in imbibed seeds. II. Polysome formation during imbibition. Journal of Biological Chemistry 240, 1675-1680.

Mascarenhas, J. P. \& Bell, E. (1969). Protein synthesis during germination of pollen. Studies on polyribosome formation. Biochimica et biophysica acta 179, 199-203.

Rado, T. A. \& Cochrane, V. W. (1971). Ribosomal competence and spore germination in Fusarium solani. Journal of Bacteriology (In press).

SCHNeIDER, W. C. (1957). Determination of nucleic acids in tissues by pentose analysis. In Methods in Enzymology, vol. 3, pp. 680-684. Edited by S. P. Colowick and N. O. Kaplan. New York: Academic Press.

Staples, R. C., App, A. A., McCarthy, W. J. \& Gerosa, M. M. (I966). Some properties of ribosomes from uredospores of the bean rust fungus. Contributions of the Boyce Thompson Institute 23, $159-164$.

Staples, R. C., Bedigian, D. \& Williams, P. H. (I968). Evidence for polysomes in extracts of bean rust uredospores. Phytopathology 58, I5I-I54.

VAN EtTEN, J. L. (1968). Protein synthesis during fungal spore germination. I. Characteristics of an in vitro phenylalanine incorporating system prepared from germinated spores of Botryodiplodia theobromae. Archives of Biochemistry and Biophysics 125, 13-21.

WEGENER, W. S. \& ROMANO, A. H. (1963). Zinc stimulation of RNA and protein synthesis in Rhizopus nigricans. Science, Washington 142, 1669-1670.

YanAGITA, T. (1957). Biochemical aspects on the germination of conidiospores of Aspergillus niger. Archiv für Mikrobiologie 26, 329-344. 